EURASIAN RESEARCH JOURNAL,

ERJ, Vol. 3, No. 2, pp. 7-18, July 2021

ISSN 2519-2442, KAZAKHSTAN

Research Article

\title{
ANALYZING MULTIPLE BUBBLES IN THE USDKZT EXCHANGE RATE USING THE GSADF TEST
}

Mert URAL ${ }^{1}$

1 Dokuz Eylul University, 35210 Izmir, Turkey; e-mail: mert.ural@deu.edu.tr; ORCID: 0000-0003-3252-846X

\begin{abstract}
Since most of the financial crisis caused by the bursting bubble of financial assets, the investigation of bubble behaviors and the early detection for the prevention of adverse economic consequences is important. This paper investigates whether multiple price bubbles exist in USDKZT exchange rate on the basis of a recursive right tailed Generalized Supremum Augmented Dickey Fuller Test (GSADF) developed by Phillips, Shi and Yu (2015), as well as to determine date stamps of the price bubbles. In this regard, we performed GSADF test by using weekly closing prices of the nominal exchange rate for the period between 23.08.2015 to 04.04.2021. In line with the empirical findings obtained, two explosive bubbles are detected in 2018 and 2020 when USDKZT exchange rate deviates from fundamental value. Our findings suggest that due to the possibility of bubble repetition, GSADF has been verified to be a better test for detecting bubbles.
\end{abstract}

Keywords: Multiple Bubbles, USDKZT Exchange Rate, GSADF Unit Root Test JEL Code: C58, G10, E60 


\section{INTRODUCTION}

Bubbles caused by excessive price inflation in financial asset prices and the explosion of these bubbles in the following periods threaten economic stability (Afsar and Dogan, 2019). As a matter of fact, as seen in the latest 2008 global crisis experience, the financial collapse as a result of the explosion of bubbles, their contagious effects through trade and / or capital movements and the large-volume rescue packages created to prevent contamination are the most serious indicators of this (Ahmed et al., 2016). For this reason, the investigation of ballooning behavior in asset prices and their frequency over time is of great importance for global economic stability, especially in emerging markets.

The rapid and continuous increases in asset prices suggest that there is a price bubble that is not considered rational. The price bubble is expressed as a situation where the actual value in the market increases rapidly and diverges from the fundamental value (Ghosh, 2016; Hepkorucu and Genc, 2019; Iskenderoglu and Akdag, 2019; Diba and Grossman, 1988). If these two values are not equal, it means that risk and uncertainty are gradually increasing (Hu and Oxley, 2017). Price bubbles are associated with a collapse following rapid increases in real and financial asset prices (Malkiel, 2010). Price bubbles create a self-sustaining cycle by adding new buyers on the basis of the "herd psychology" of the investors.

Asset price bubbles are affected by demand-side shocks. After a while, investors start selling assets in their portfolios, thinking that asset prices have reached the highest level. This time, as a result of herd psychology operating in the opposite direction, asset prices are falling dramatically (Buyukduman, 2014; Kansu, 2011: 22-26; Lind, 2009). This process refers to the formation, growth and eventual explosion of the price bubble.

Traditionally, in order to detect bubbles in the prices of assets, Chow and CUSUM tests are recommended, as well as variance, stationarity, unit root and/ or cointegration tests. However, SADF (Supremum Augmented Dickey-Fuller) and GSADF (Generalized Supremum Augmented Dickey-Fuller) tests, proposed in Phillips et al. (2011) and Phillips et al. (2015) studies, have been widely used determining price bubbles.

The recursive GSADF test, which analyzes the time series at a single level from beginning to end, examines in more detail and therefore contains more information than similar methods that take into account right-tailed distributions. This situation allows the analysis of the multi-price bubble structure in the whole time series (Hepkorucu and Genc, 2019). GSADF method has a datestamping strategy that captures both the existence of price bubbles and the beginning and ending points of a bubble (Phillips et al., 2011).

The main purpose of this study is to examine the presence of price bubbles in USDKZT exchange rate with GSADF test, as well as to determine datestamps of the price bubbles. The distinctive contribution of the study is that as far as we have determined, there was no previous study on the determination of price bubbles on the USDKZT exchange rate in the literature.

The remainder of this paper proceeds as follows. Section 2 attempts to review the relevant literature. Section 3 details the general models. Section 4 describes the USDKZT exchange rate data and presents the empirical results. Section 5 
contains some concluding remarks.

\section{LITERATURE REVIEW}

There are many studies in the literature that have investigated the existence of price bubbles in stock markets, foreign exchange markets, commodity markets, precious metal markets, crypto money markets and housing markets.

Although various methodologies are used to determine price bubbles, the GSADF test used by Phillips, Shi and Yu in 2015 has come to the fore in the determination of multiple price bubbles in recent years. Some studies using the GSADF test are grouped as follows:

Some studies using the GSADF test to determine price bubbles in stock markets, foreign exchange markets, commodity markets and precious metal markets: Bettendorf and Chen (2013), Jiang et al. (2015), Hu and Oxley (2016), Korkmaz et al. (2016), Pavlidis et al. (2017), Rasekhi et al. (2017), Akkaya (2018), Celik et al. (2019), Kilic (2020) and Gulcan et al. (2021).

Studies investigating price bubbles in cryptocurrencies using the GSADF test: Cheung et al. (2015), Landgraf (2016), Wei (2017), Corbet et al. (2018), Bouri et al. (2018), Ceylan et al. (2018), Zeren and Esen (2018), Su et al. (2018), Mete et al. (2019), Hepkorucu and Genc (2019), Enoksen et al. (2020) can be specified as Sahin (2020).

Studies investigating the price bubbles in housing markets using the GSADF test: Zeren and Erguzel (2015), Engsted et al. (2016), Shi et al.(2016), Escobari and Jafarinejad (2016), Coskun and Jadevicius (2017) Afsar and Dogan (2018), Evrim et al. (2018), Hu and Oxley (2018), Iskenderoglu and Akdag (2019), Gokce and Guler (2020), Abioglu (2020).

\section{METHODOLOGY}

The regression model used in determining price bubbles can be written as follows (Phillips et al. 2015):

$$
y_{t}=d T^{-\eta}+\theta y_{t-1}+\varepsilon_{t}, \varepsilon_{t} \square^{i d d} N\left(0, \alpha^{2}\right), \theta=1
$$

Here; $d$ is the intercept term, $T$ is the number of observations, the coefficien $\eta$ is constant and $T \rightarrow \infty$ is the localization-confinement coefficien which controls the magnitude of drift, and $y t-1$ means a delayed value of the respective asset series; $\varepsilon t$ represents the error term with constant variance that has mean 0 . In the Phillips, Shi and $\mathrm{Yu}$ approach, the null hypothesis $\left(\mathrm{H}_{0}\right)$ assumes that the asset price follows a random walk process with an asymptotically negligible shift, while under the alternative hypothesis $\left(\mathrm{H}_{1}\right)$, it shows the existence of a bubble in prices (Ceylan et al., 2018). When equation (1) is solved, the following equation is obtained, which gives the deterministic shift $\frac{d t}{T^{\eta}}$ :

$y_{t}=d \frac{t}{T^{-\eta}}+\sum_{j=1}^{t} \varepsilon_{j}+y_{0}$ 
Here, with $\eta>0$, the drift is small compared to a linear trend. If $\eta>1 / 2$, the drift is small relative to the martingale component of $y t$. In the case of $\eta>1 / 2$, the standardized $T^{-\frac{1}{2}} y_{1}$ output treats asymptotically like Brownian motion involving drift. In the study, $\eta>1 / 2$ case, in which the magnitude level of $y t$ is the same as the pure random walk has been discussed.

The recursive approach includes an ADF-style regression with drift windows for stationarity testing. The regression with a drift window starts from the $r_{1}^{\text {th }}$ portion of the total sample (T) and ends at the $r_{2}^{\text {th }}$ portion. Where $r_{2}=r_{1}+r_{w}$ ve $r_{w}>0$ is the partial window size of the regression. The empirical regression model, including $H_{0}: \hat{\beta}=1$ ve $H_{1}: \hat{\beta}>1$ ve can be written as:

$$
\Delta y_{t}=\hat{\alpha}_{r_{1}, r_{2}}+\hat{\beta}_{r_{1}, r_{2}} y_{t-1}+\sum_{i=1}^{k} \hat{\psi}_{r_{1}, r_{2}}^{i} \Delta y_{t-i}+\hat{\varepsilon}_{t}
$$

Here, $k$ (temporary) is the number of delays. $T_{w}=\left[T_{r_{w}}\right]$ is the base function showing the integer part [.], including the total number of observations. This is shown $A D F_{r}^{\prime \prime}$ in the form of ADF statistics based on regression. Thus, it is understood that this type of floating window regression is used especially for multiple bubble detection. Asymptotic critical values of GSADF test statistics are determined by Monte Carlo simulations.

The GSADF test is based on recursively repeated ADF test regressions on subsamples of the total number of observations. The window size $\left(r_{w}\right)$ spreads from $r_{0}$ (the smallest sample window size) to 1 (the largest sample window size) and expresses the total sample size. The $r_{1}$ (starting point of the sample) is fixed at 0 . The window size is equal to rw, with $r_{2}$ at the sample ending point. The sample starting point $r_{1}$ changes between $r_{0}$ to 1 . It is shown as the ADF statistics of a sample ranging from 0 to $r_{2}$ (Zeren and Esen, 2018). Figure 1 below shows the GSADF process in the context of floating windows in the sample range (Caspi, 2013).

Figure 1. GSADF Test Process Sampling Range [0,1]

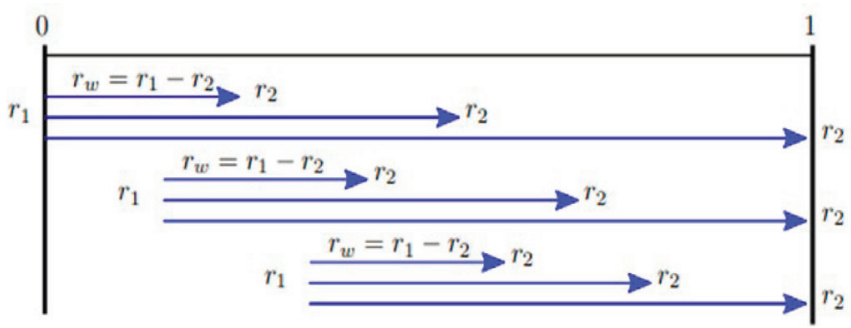

Source: Author's estimates

In the GSADF test, the sample starting point is not fixed and is shifted over the starting and ending points. Thus, it becomes possible to detect multiple bubbles with the GSADF test. Nonlinear structures and structural breaks also take into account by GSADF (Cagli and Mandaci, 2017).

The GSADF test statistic is defined as the largest ADF statistic in all applicable r1 and $\mathrm{r} 2$ ranges in this double iteration, and GSADF $\left(r_{0}\right)$ is shown as follows (Phillips et al., 2015; Enoksen et al., 2020). 


$$
\operatorname{GSADF}\left(r_{0}\right)=\sup _{\substack{r_{r_{2}} \in\left[r_{0}, 1\right] \\ r_{1} \in\left[0, r_{2}-r_{0}\right]}}\left\{A D F_{r_{1}}^{r_{2}}\right\}
$$

As previously shown in equation (1), the limit distribution of the GSADF test statistic, where $\mathrm{W}$ is a standard Wiener process and $r_{\mathrm{w}}=r_{2}-r_{1}$ can be written as follows:

$$
=\sup _{\substack{r_{2} \in r_{r_{1}, 1,1} \\ r_{1}\left[0, r_{2}, r_{0}\right]}}\left\{\frac{\frac{1}{2} r_{w}\left[W\left(r_{2}\right)^{2}-W\left(r_{1}\right)^{2}-r_{w}\right]-\int_{r_{1}}^{r_{2}} W(r) d r\left[W\left(r_{2}\right)-W\left(r_{1}\right)\right]}{r_{w}^{\frac{1}{2}}\left\{r_{w} \int_{r_{1}}^{r_{2}} W(r)^{2} d r-\left[\int_{r_{1}}^{r_{2}} W(r) d r\right]^{2}\right\}^{\frac{1}{2}}}\right\}
$$

If the GSADF test statistics calculated with the help of equation (4) and therefore equation (5) are greater than the critical values calculated as a result of Monte Carlo simulations, the null hypothesis claiming that there are no financial bubbles is rejected (Celik et al., 2019). The rejection of the null hypothesis indicates the existence of rational bubbles in price series (Gokce and Guler, 2020).

Actually, if $T$ is small, then $r_{0}$ should be large enough to allow sufficien observation for the initial prediction. If $\mathrm{T}$ is large, $r_{0}$ may be smaller so that the GSADF test can detect an early burst / bubble event. A rule in simple functional form in the form of $r_{0}=0,01+\frac{1,8}{\sqrt{T}}$ is proposed for the selection of the appropriate window size based on extensive simulation findings. When $r_{0}$ (the minimum window size) gets smaller, the critical value of the GSADF test statistic increases (Phillips et al. 2015).

After detecting the presence of bubbles, the formation periods of the bubbles are determined using retrospective SADF (Backwards sup ADF - BSADF) statistics series. BSADF statistical sequences are obtained using right-tailed ADF tests for samples of a backward expanding structure. BSADF and GSADF statistics can be represent as follows (Caspi, 2013):

$$
\begin{aligned}
& \left\{B S A D F_{r_{2}}\left(r_{0}\right)\right\}_{r_{2} \in\left[r_{0}, 1\right]} \\
& \operatorname{GSADF}\left(r_{0}\right)=\sup _{r_{2} \in\left[r_{0}, 1\right]}\left\{B S A D F_{r_{2}}\left(r_{0}\right)\right\}
\end{aligned}
$$

By comparing the BSADF sequences with the set of right-tailed critical values the dates of formation of the bubbles are determined (Ceylan et al., 2018).

\section{DATA AND EMPIRICAL RESULTS}

Because of the weakening of the Chinese yuan and the decrease in the price of Brent crude oil from early 2015, the pressure on the economy of Kazakhstan was exacerbated. This economic condition forced the National Bank of Kazakhstan to switch to a floating rate in August 20, 2015. Hence, analysis period started from the date of regime change. In the study, the existence of speculative price bubbles in USDKZT exchange rates since 2015 and the bubble formation dates were determined by the right-tailed GSADF unit root test proposed by Phillips et al. (2015). It has been tried to be determined. weekly closing prices 
of USDKZT exchange rates between 23.08.2015-04.04.2021 were used in the study. The data are taken from investing.com database.

The empirical findings of the study have been interpreted by presenting them with the help of tables and graphics. The appropriate window size for the USDKZT exchange rate series was calculated with the $r_{0}=0,01+\frac{1,8}{\sqrt{T}}$ formula and was
determined as 34 .

The usual descriptive statistics for USDKZT exchange rate series are summarized in Table 1. According to Table 1, while the maximum and minimum values are 448.1250 and 240.2500 respectively, the volatility (standard deviation) value is also high (40.50798). The coefficien of skewness (0.056524) is positive and there is a right skewed distribution. The kurtosis coefficien is 2.58028 and there is a platykurtic feature. It means that USDKZT exchange rate series exhibit asymmetric and platykurtic properties Additionally, by Jarque-Bera statistics and corresponding $\mathrm{p}$-value we accept the null hypothesis that exchange rate series are well approximated by the normal distribution.

Table 1. Descriptive statistics of USDKZT exchange rate series

\begin{tabular}{ll}
\hline & USDKZT \\
\hline Observation & 294 \\
\hline Mean & 360.5772 \\
\hline Minimum & 240.2500 \\
\hline Standard Deviation & 448.1250 \\
\hline Skewness & 40.50798 \\
\hline Kurtosis & 0.056524 \\
\hline Jarque-Bera & 2.580289 \\
(Prob.) & 2.314479 \\
\hline
\end{tabular}

Source: Author's estimates

From the descriptive graph presented in Figure 1, several increase periods can be observed especially in 2018 and 2020. These graphical expositions show that USDKZT exchange rate series exhibit price bubbles.

Figure 1. Weekly closing prices for USDKZT exchange rate series

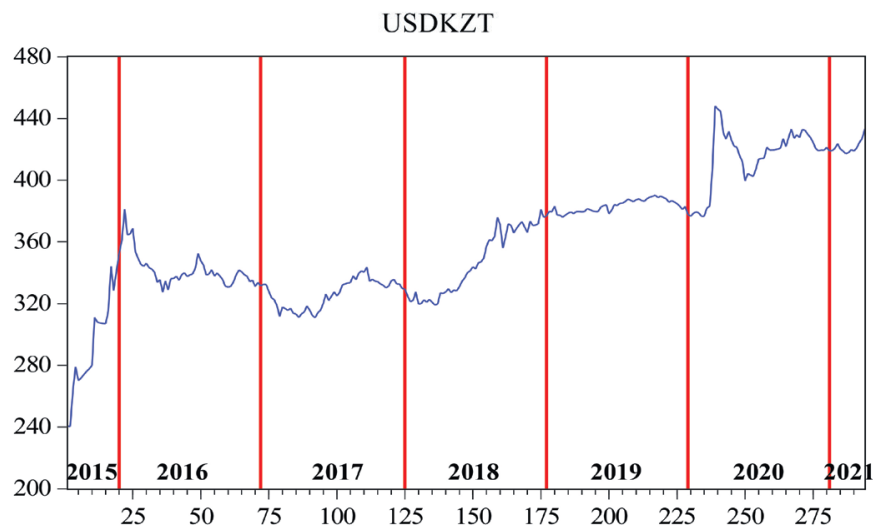

Source: Author's estimates

In the USDKZT exchange rate series, it is important to determine whether the 
upward trends experienced especially in 2018 and 2020 after the regime change are price bubbles, as well as the start and end dates of the bubble. In this context, the GSADF method can offer an "early warning" tool (Ceylan et al., 2018: 268).

Table 2 shows the GSADF test statistics given in equation (4) and equation (5) for the USDKZT exchange rate series. Critical values are obtained with 2000 trials based on Monte Carlo simulations according to the appropriate window size (Gokce and Guler, 2020). Accordingly, (294-34) x2,000 = 520,000 regressions were estimated. In this context, a GSADF test ended in a calculation process of approximately 12 hours. The GSADF test statistic is significantly greater than the critical value at $99 \%$ confidence level. Statistically, it has been understood that there are price bubbles in the USDKZT exchange rate series for the period of 23.08.2015-04.04.2021.

Table 2. GSADF Test Statistic Results

\begin{tabular}{cccccc}
\hline Variable & $\begin{array}{c}\text { GSADF } \\
\text { Test Statistic }\end{array}$ & Test Critical Values & $\begin{array}{c}\text { Window } \\
\text { Size }\end{array}$ & Lags & $\begin{array}{c}\text { Price } \\
\text { Bubbles }\end{array}$ \\
\hline USDKZT & $3.840692 *$ & $\begin{array}{l}2.930127(99 \%) \\
2.120765(95 \%)\end{array}$ & 34 & 0 & YES \\
& & $1.951242(90 \%)$ & & & \\
\hline
\end{tabular}

Source: Author's estimates

According to Table 1, one can specify that the USDKZT exchange rate contains explosive sub-periods. The null hypothesis that $H_{0}: r=1$ at $1 \%$ significance critical value is rejected because the GSADF test statistic (3.840692) is greater than the critical value (2.930127).

After determining the existence of price bubbles, the number of bubbles formed during the analysis period and the start-end dates of the bubbles can be observed with the BSADF method as explained before. The critical value of the BSADF sequence indicates the starting point of the price bubble, and the crossing downwards indicates the ending point of the price bubble. In addition, the larger the part of the BSADF sequence that remains above the critical value, the higher the impact of the speculative price bubble on the market will be.

In Figure 2, the BSADF series estimated from USDKZT exchange rate series, are compared with the critical value series obtained at 95\% confidence level. The start and end dates of speculative price bubbles are shown in shades. The USDKZT exchange rate, the $95 \%$ critical value, the GSADF statistic are represented by upper, middle and bottom curves, respectively. The shadows are sub-periods with bubbles. 
Figure 2. GSADF test of the USDKZT exchange rate.

GSADF test

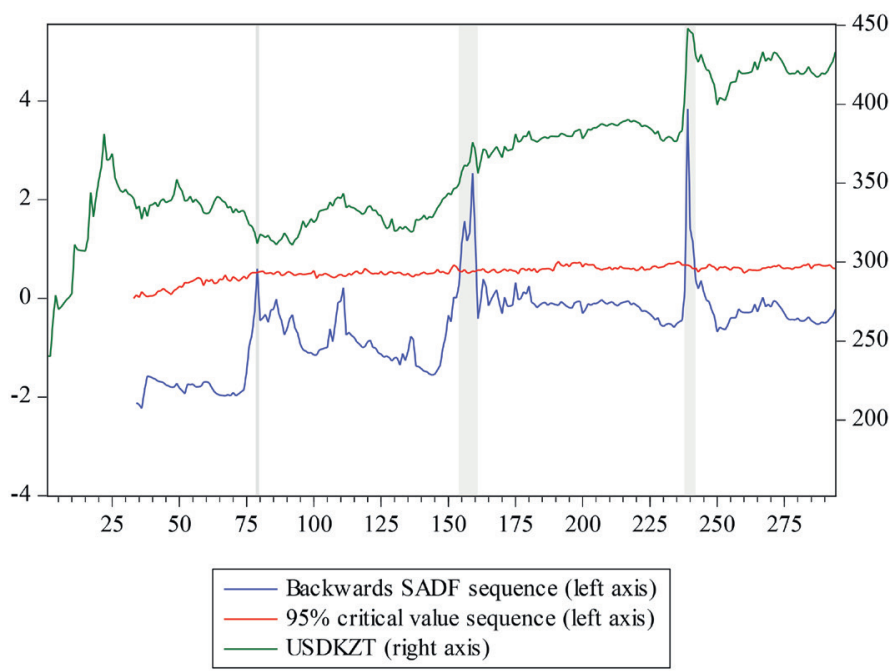

Source: Author's estimates

From Figure 2, if we ignore the minor violation of December 19, 2017, we identify two significant price bubbles in 2018 and 2020. The first bubble originates on July 29, 2018 and bursts on September 16, 2018 which is a duration of nearly eight weeks. The second bubble begins on March 8, 2020 and collapses on April 5, 2020 which is a duration of nearly 5 weeks. For the first bubble period; US sanctions on Turkey and Russia, escalation of US-China trade disputes, interest rate rising in Turkey and Russia can be listed among the important developments in the relevant date range. For the second bubble period; the plummeting oil prices due to the Covid-19 pandemic and the Saudi-Russian price war weakened tenge. At the beginning of April 2020, the USDKZT exchange rate fell to a record low with a loss of $14.6 \%$ in the last month due to the sudden drop in oil prices.

\section{CONCLUSION}

Asset prices can fluctuate greatly due to speculative movements. This study investigates whether multiple price bubbles exist in USDKZT exchange rate, as well as to determine date stamps of the price bubbles. In this regard, by using weekly closing prices of the USDKZT nominal exchange rate for the period between 23.08.2015 to 04.04.2021, a recursive right tailed Generalized Supremum Augmented Dickey Fuller Test (GSADF) proposed by Phillips et al. (2015) performed.

The empirical findings show that there have been two explosive bubbles in 2018 and 2020. It can be said that especially price bubbles are caused by shocks originating from foreign or domestic economic events. Price bubbles create a self-sustaining cycle by adding new buyers on the basis of the "herd psychology" of the investors. Herd behavior can become increasingly important when the market is dominated by large institutional investors. For the measurement 
of herd psychology, the Markov Switching approach as well as Cross-Sectional Absolute Deviation (CSAD) developed by Chang et al. (2000). But analysis of herd behavior is not within the scope of this study.

Due to the price bubbles seen on analysis period, it can be said that the USDKZT exchange rate is sensitive to speculative movements. Therefore, it can be emphasized that both investors, policy makers and/or financial market regulators should take the necessary precautions regarding these speculative movements. Within the scope of preventive measures against speculative movements, it would be appropriate to support the possible damages that investors and/or speculators may cause to the system with deterrent monetary penalties or taxes. 


\section{REFERENCES}

Abioglu, Vasif (2020). "Turkiye konut piyasasinda balon olusumlari: bolgesel inceleme" [Bubble formations in the Turkish housing market: regional analysis]. Finansal Arastirmalar ve Calismalar Dergisi 12(22): 1-14.

Afsar, Asli and Emrah Dogan (2018). "Analyzing asset of bubbles in the housing market with right-tailed unit root tests: the case of Turkey". Journal of Business Economics and Finance 7(2): 139-147.

Ahmed, Ehsan, J. Barkley Rosser, Jr. and Jamshed Y. Uppal (2016). "Financialization and speculative bubbles - international evidence". CAMA Working Paper No.6/2017: 1-28.

Akkaya, Murat (2018). "Borsa Istanbul hisse senedi getirilerinde balon olusumu uzerine bir uygulama" [An application on the bubble formation in Istanbul stock returns]. C.U. Iktisadi ve İdari Bilimler Dergisi 19(1): 188-200.

Bettendorf, Timo and Chen Wenjuan (2013). "Are there bubbles in the sterlingdollar exchange rate? New evidence from sequential ADF tests". Economics Letters 120(2): 350-353.

Bouri, Elie, Syed Jawad Hussain Shahzad and David Roubaud (2018). "Coexplosivity in the cryptocurrency market". Finance Research Letters 29(c): 178183.

Buyukduman, Ahmet (2014). Bir Kent Efsanesi Konut Balonu [An Urban Legend Housing Bubble]. Istanbul: Scala Yayincilik.

Caspi, Itamar (2013). "RTADF: Testing for bubbles with EViews". Munich Personal RePEc Archive 58791: 1-16.

Cagli, Efe C. and Pinar. E. Mandaci (2017). "Borsa Istanbul'da rasyonel balon varligi: Sektor endeksleri uzerine bir analiz" [Rational bubble existence in Borsa Istanbul: An analysis on sector indices]. Finans Politik and Ekonomik Yorumlar No. 629: 63-76.

Celik, Ismail, Hilmi T. Akkus and Nazligul Gulcan (2019). "Investigation of rational bubbles and volatility spillovers in commodity markets: Evidences from precious metals". Journal of Mehmet Akif Ersoy University Economics and Administrative Sciences Faculty 6(3): 937-951.

Ceylan, Fatih, Ramazan Ekinci, Osman Tuzun, Hakan Kahyaoglu (2018). “Kripto para piyasasinda balonlarin tespiti: Bitcoin ve etherium ornegi" [Detection of bubbles in the cryptocurrency market: Case of Bitcoin and etherium]. Bussines ve Management Studies: An International Journal 6(3): 263-274.

Chang, Eric C., Joseph W. Cheng and Ajay Khorana (2000). "An examination of herd behaviour in equity markets: An international perspective". Journal of Banking and Finance 24(10): 1651-1679.

Cheung, Adrian, Eduardo Roca and Jen-Je Su (2015). “Crypto-Currency Bubbles: an Application of the Phillips-Shi Yu (2013) Methodology on Mt. Gox Bitcoin Prices". Applied Economics 47(23): 2348-2358.

Corbet, Shaen, Brian Lucey and Larisa Yarovaya (2018). "Datestamping the Bitcoin and ethereum bubbles". Finance Research Letters 26(c): 81-88.

Coskun, Yener, Arvydas Jadevicius (2017). "Is there a housing bubble in Turkey?". Real Estate Management and Valuation 25(1): 48-73. 
Diba, Behzad and Herschel Grossman (1988). "Explosive rational bubbles in stock prices?". American Economic Review 78(3): 520-530.

Engsted, Tom, Simon J. Hviid and Thomas Pedersen (2016). "Explosive bubbles in house prices? Evidence from the OECD countries". Journal of International Financial Markets, Institutions and Money 40(c): 14-25.

Enoksen, Fredrik A., Christian J. Landsnes, Katarína Lucivjanská and Peter Molnár (2020). "Understanding risk of bubbles in cryptocurrencies". Journal of Economic Behavior and Organization 176: 129-144.

Escobari, Diego and Mohammad Jafarinejad (2016). "Date stamping bubbles in real estate investment trusts". The Quarterly Review of Economics and Finance 60(c): 224-230.

Evrim, Pinar M. and Efe C. Cagli (2018). "Turkiye konut piyasasinda balon var mi? Istatistiki bolge birimleri uzerine bir analiz" [Is there a bubble in the Turkish housing market? An analysis on statistical regional units]. Finans Politik ve Ekonomik Yorumlar Dergisi 55(646): 85-113.

Ghosh, Bikramaditya (2016). "Rational bubble testing: An in-depth study on CNX nifty". Asian Journal of Research in Banking and Finance 6(6): 10-16.

Gokce, Atilla and Ilkay Guler (2020). "Sag-yonlu ADF sinamalari ile Ankara ilinde konut balonu arastirmasi" [Right-sided ADF tests and housing bubble research in Ankara province]. Ankara Haci Bayram Veli Universitesi Iktisadi ve Idari Bilimler Fakultesi Dergisi Special Issue: 94-116.

Gulcan, Nazligul, Namika Boyacioglu and Arife Ozdemir (2021). "Investigation of speculative bubbles in financial markets: The example of foreign exchange market”. Suleyman Demirel University Visionary Journal 12(29): 176-187.

Hepkorucu, Atilla and Sevdanur Genc (2019). "Kripto para degerleri icin spekulatif fiyat balonlarinin test edilmesi: Bitcoin uzerine bir uygulama" [Testing speculative price bubbles for cryptocurrencies: An application on bitcoin]. Veri Bilimi Dergisi 2(1): 44-50.

$\mathrm{Hu}$, Yang and Les Oxley (2016). "Are there bubbles in exchange rates? Some new evidence from G10 and emerging markets countries". University of Waikato Working Papers in Economics 16/05: 1-33.

$\mathrm{Hu}$, Yang and Les Oxley (2018). "Bubble contagion: Evidence from Japan's asset price bubble of the 1980-90s". Journal of the Japanese and International Economies 50(c): 89-95.

Iskenderoglu, Omer and Saffet Akdag (2019). "Turkiye'de reel konut fiyatlarinda balonlarin varligi uzerine uygulamali bir analiz" [An applied analysis on the existence of bubbles in real house prices in Turkey]. Business and Economics Research Journal 10(5): 1085-1093.

Jiang, Chun, Yi Wang, Tsangyoa Chang and Chi-Wei Su (2015). "Are there bubbles in Chinese RMB-dollar exchange rate? Evidence from generalized sup ADF tests". Applied Economics 47(56): 6120-6135.

Kansu, Aydan (2011). Konut Balonundan Finansal Krize: ABD Mortgage Krizi [From the Housing Bubble to the Financial Crisis: The US Mortgage Crisis]. Istanbul: Scala Yayincilik.

Kilic, Yunus (2020). "Finansal piyasalarda balon varliginin test edilmesi: BRICS-T ulkeleri ornegi". Journal of Banking and Capital Markets Research 
4(9): 11-22.

Korkmaz, Ozge, Deniz Erer and Elif Erer (2016). "Alternatif yatirim araclarinda ortaya cikan balonlar Turkiye hisse senedi piyasasini etkiliyor mu? BIST 100 uzerine bir uygulama" [Do the bubbles emerging in alternative investment instruments affect the Turkish stock market? An application on BIST 100]. BDDK Bankacilik ve Finansal Piyasalar Dergisi 10(2): 29-61.

Landgraf, Nikolaus (2016). "Testing for multiple bubbles in asset prices". Research in Business and Economics 1(1): 1-24.

Lind, Hans (2009). "Price bubbles in housing markets: Concept, theory and indicators". International Journal of Housing Markets and Analysis 2(1): 78-90.

Malkiel, Burton G. (2010). Bubbles in asset prices. CEPS Working Paper No. 200, Princeton University.

Mete, Sefa, Ayben Koy and Ersoy Hicabi (2019). "Kriptoparalarda fiyat balonu incelemesi" [Price bubble review in cryptocurrencies]. BDDK Bankacilik ve Finansal Piyasalar Dergisi 13(1): 105-120.

Pavlidis, Efthymios G., Ivan Paya and David Peel (2017). "Testing for speculative bubbles using spot and forward prices". International Economic Review 58(4): 1191-1226.

Phillips, Peter C. B., Yangru Wu and Jun Yu (2011). "Explosive behavior in the 1990s NASDAQ: When did exuberance escalate asset values?". International Economic Review 52(1): 201-226.

Phillips, Peter C. B., Shuping Shi and Jun Yu (2015). "Testing for multiple bubbles: Historical episodes of exuberance and collapse in the S\&P 500". International Economic Review 56(4): 1043-1077.

Rasekhi, Saeed, Zahra M. Elmi and Milad Shahrazi (2017). "Testing for multiple bubbles in Iranian foreign exchange market: The Application of RTADF unit root tests". The Journal of Economic Modeling Research 7 (27): 7-39.

Shi, Shuping, Abbas Valadkhani, Russell Smyth and Farshid Vahid (2016). "Dating the timeline of house price bubbles in Australian capital cities". Economic Record 92(299): 590-605.

Su, Chi-Wei, Zheng-Zheng Li, Ran Tao and Deng-Kui Si (2018). "Testing for multiple bubbles in Bitcoin markets: A generalized sup ADF test". Japan and the World Economy 46(C): 56-63.

Sahin, Eyyup E. (2020). "Kripto para fiyatlarinda balon varliginin tespiti: Bitcoin, IOTA ve ripple ornegi". Selcuk Universitesi Sosyal Bilimler Enstitusu Dergisi 43: 62-69.

Wei, Deng (2017). "Price bubbles in bitcoin: Evidence, causes and implications". Journal of Shanghai University of Finance and Economics 19(2): 50-62.

Zeren, Feyyaz and Oylum S. Erguzel (2015). "Testing for bubbles in the housing market: Further evidence from Turkey”. Financial Studies 19(1): 40-52.

Zeren, Feyyaz and Sinan Esen (2018). "Gelecegin para birimi ya da sadece bir balon: Bitcoin" [The currency of the future or just a bubble: Bitcoin]. Balikesir Universitesi Sosyal Bilimler Enstitusu Dergisi 21(39): 433-448. 